\title{
GNSS測量による地盤変動量を考慮した 海面変動量の推定
}

\author{
内藤 了二 1 - 鮫島 和範 $2 \cdot$ 近藤 泰徳 $3 \cdot$ \\ 伊藤 直和 $3 \cdot$ 川口 浩二 4 \\ 1 正会員 国土交通省 国土技術政策総合研究所 沿岸海洋・防災研究部 \\ （干239-0826 神奈川県横須賀市長瀬 3-1-1） \\ E-mail: naitou-r852a@mlit.go.jp \\ 2 国土交通省 国土技術政策総合研究所 沿岸海洋・防災研究部 \\ （干239-0826 神奈川県横須賀市長瀬 3-1-1） \\ 3 正会員 （一社）海洋調査協会（干103-0023 東京都中央区日本橋本町 2-8-6） \\ 4 正会員 (国研) 海上・港湾・航空技術研究所 港湾空港技術研究所 海象情報研究グループ \\ ( ₹239-0826 神奈川県横須賀市長瀬 3-1-1)
}

\begin{abstract}
長期海面変動量の推定は，定期的に地盤変動量を観測し補正しなければならない。近年，高齢化に伴う 測量技術者の不足，費用面の問題があり，簡易手法で地盤高さを管理することが喫緊の課題である。本研 究は，GNSS 測量による地盤変動量を考慮した海面変動量の推定を試みた。 三河港は，検潮記録をもとに 推定した年平均海面変動量は，-3.20 (mm/year)であった。伊勢湾沿岸の鳥羽，名古屋港，鬼崎でも，同様に 下降していた。三河港での球分体楕円体高は，GNSS 測量によると直近 5 年間で $68.4 \mathrm{~mm}(13.7 \mathrm{~mm} / \mathrm{year})$ 上 昇していた. また，セミダイナミックパラメータによる 1997 年から 19 年間での地盤変動量は, $120 \mathrm{~mm}$ (6.32 mm/year) 上昇していた。地盤変動を考慮すると三河港での年平均海面変動量は, 3.12 ( $\mathrm{mm} / \mathrm{year})$ 上昇 と推定された。 さらに，被災時の復旧段階での検潮所の高さ管理の手法を提案した。
\end{abstract}

Key Words : long term statistics, mean sea level, sea-level rise, ground elevation, GNSS - leveling,

\section{1. はじめに}

常設検潮所で取得される平均海面水位は，観測基淮面 からの高さであるが，長期海面変動量を推定するには， 定期的に検潮所での地盤変動量を観測し平均海面水位か ら地盤変動量を補正することが必要である．また，高齢 化による測量技術者の不足，費用面の問題があり，簡易 手法で地盤高さを管理することが喫緊の課題である. と りわけ港湾域では，埋立後の圧密等による地盤沈下など 特殊な地盤変動傾向を示寸ことがあるため, 継続的に地 盤変動を監視することが必要である.

これまで，平均海面水位の海面変動に関わる研究例に は以下の報告がある。檀原 ${ }^{1}$ は，日本は地款変動が激し く，黒潮や親潮などの海況が不安定であるため，年平均 潮位值を用いて, 広い海域に共通する海水淮の変動とそ れからのずれとしての地殼上下変動を論じた．村上ら 22 は，1950年頃から1990年までの検潮記録を収集して，観 測基準面の変動を取り除いた平均海面水位の経年変動, 潮位の変動特性とその要因について論じた. 櫻井ら゙3は, 水準測量結果から求めた地盤の上下変動量を, 各検潮所
の取付水準点の標高と取付水準点から球分体までの比高 を用いて，1970年から2003年の検潮記録から海面変動量 を推定している．また，GPS連続測定結果から1996年か ら2002年の地盤上下動の変化傾向を用いて海面変動量を 推定している. 三浦ら ${ }^{4}$ は, GPS-P点ならびに検潮所近傍 の電子基準点を用いて，地盤上下変動の除去の他に，気 圧補正・潮汐補正を行ったデータから海面変動量を推定 している.内藤ら $ら^{5} は ，$ 全国10港湾を対象に，長期検潮 記録加ら潮汐・気圧・地盤変動の影響を抽出・除去する ことにより，ノイズ成分を除去して平均海面水位を推定 する方法を設定し，その長期的な変動特性を考察した。

常設検潮所においてGNSS測量による地盤変動の監視 を同時に行い，正確な地盤変動量を捉えることは，海面 変動量を推定する上で重要である. しかしながら, GNSS 測量を用いて, 球分体楕円体高の地盤変動を考慮した海 面変動量を推定した研究例は殆どない，そこで本研究で は，GNSS測量による地盤変動量を考慮した長期の海面 変動量の推定を試みるとともに, GNSS測量に基づく被 災発生時の緊急復旧段階における検潮所の地盤高さ管理 の考え方を示した。 


\section{2. 研究方法}

\section{（1） 三河港検潮所における潮位観測}

三河港検潮所は，図-1 に示寸愛知県豊橋市に位置する。 比較対象とした検潮所は，鳥羽，鬼崎，名古屋港，舞阪 の 4 力所である. 図-2 に検潮機器の設置状況を示す. 検 潮所球分体は，検潮井戸の天端面に真鍮鋲を設置し，高 さの管理を定期的に行っている．潮位観測は，フース型 検潮器を使用してデータを取得し, 検潮記録を整理した。 検潮機器の動作確認と検潮所内の鍾測尺による基準測定 は，1 ケ月に 1 回行なっている.

\section{(2) GNSS 測量}

図-3 に，GNSS 観測状況を示寸。測量方法は，GNSS スタティック測量とした. 測量期間は, 2011 年から 2016 年である．表-1 には，GNSS 測量の諸元を示寸．高さの 基準はジオイド高に左右されない楕円体高とした. GNSS 測量は，三河港検潮所階段下に B.M.を設標して， 既知点を電子基準点 3 箇所（田原，豊橋 2 ，豊橋 $\mathrm{A}$ ）。 とした． 既知点の選定は，図-4 に示寸ように，三河港検 潮所との間に平面的に断層を挟まない位置で，検潮所よ り $60 \mathrm{~km}$ 以内かつ，検潮所を中心にほぼ正三角形の配置 とした．三河港西側には，活断層が 2 か所（横須賀，深 溝）存在している。

B.M.から検潮所球分体までの高さは，直接水準測量を 行なった．球分体の楕円体高は，地盤変動量を考慮する ため，セミ・ダイナミック補正パラメータ7を用いて， 既知点の測量成果（元期）を現在の位置（今期）に補正 後, 既知点の今期座標值を固定し網平均計算により 1997 年からの地盤変動量を算出した. セミ・ダイナミック補 正とは，電子基準点のみを既知点とする広域測量で使用 する補正で, セミダイナミックパラメータとは $5 \mathrm{~km}$ メッ シュの地款変動量7)である.

\section{（3） 平均海面水位と海面変動量の推定}

平均海面水位の推定には, 年平均海面水位 (T.P 換算) を用い, 1998 年から 2016 年までの 19 年間の検潮記録を 整理した. 三河港周辺での平均海面水位を比較するため, 図-1 に示寸鳥羽，名古屋港，鬼崎の検潮記録 8), 9, 10), 11)を 整理した。

平均海面水位の時系列データは, 自己相関が存在する 可能性があるため，コレログラムを用いてデータの独立 性を確認した. 年平均海面水位変動の傾向を調べるため, マンケンドール検定による両側検定を行った．年平均海 面水位変動量は，単回帰分析により推定した．有意水準 は 5\%とした。これらの統計解析は，データ解析環境 R

(Ver3.1.2) を行った.

地盤変動を考慮した三河港での年平均海面変動量は,
セミダイナミックパラメータによる年平均の地盤変動量 と年平均海面水位の推定值との差分から算出した.

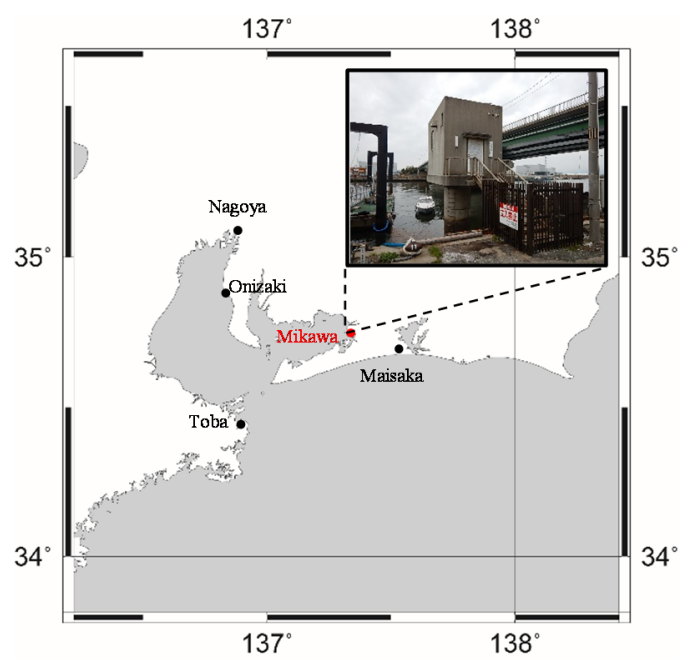

図-1＼cjkstart伊勢湾沿岸周辺の検潮所位置図

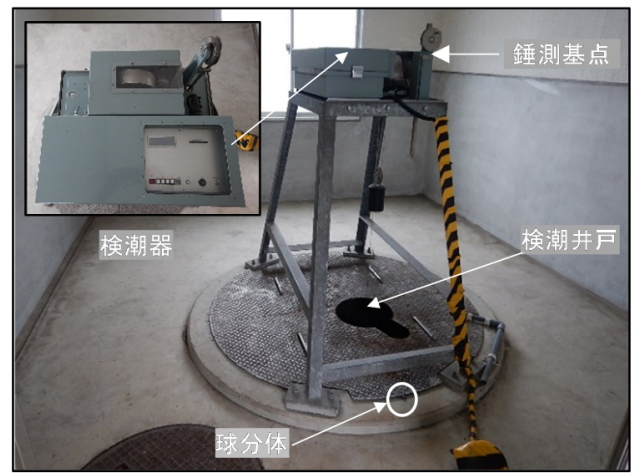

図-2 三河港検潮所の検潮機器設置状況

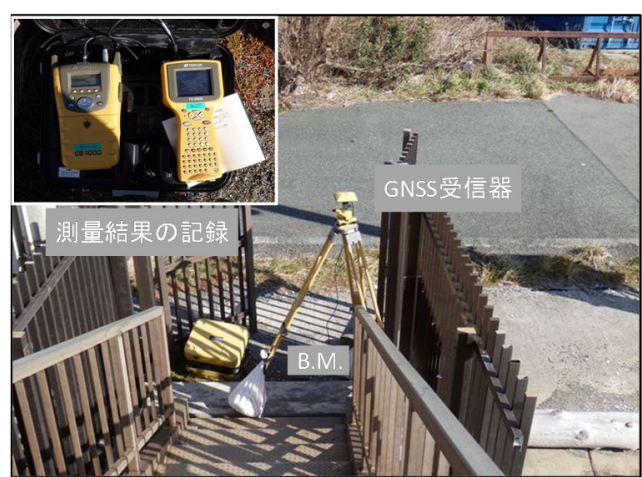

図-3ＧNSS による現地観測状況

表-1 GNSS 測量の諸元

\begin{tabular}{|c|c|}
\hline 測量方法 & GNSSスタティック測量 \\
\hline 測量機器 & 1 級GNSS測量機 \\
\hline 観測時間 & 6時間 \\
\hline 観測設定 & $\begin{array}{l}\text { データ取得間隔 } 30 \text { 秒 } \\
\text { 最低高度角 } 15^{\circ} \\
\text { 最小衛星個数 } 4 \text { 4個 }\end{array}$ \\
\hline 既知点 & 電子基準点 (3力所) \\
\hline 計算条件 & $\begin{array}{l}\text { PCV補正あり } \\
\text { セミ・タタイナミック補正パラメータ } \\
(2011-2016)\end{array}$ \\
\hline
\end{tabular}




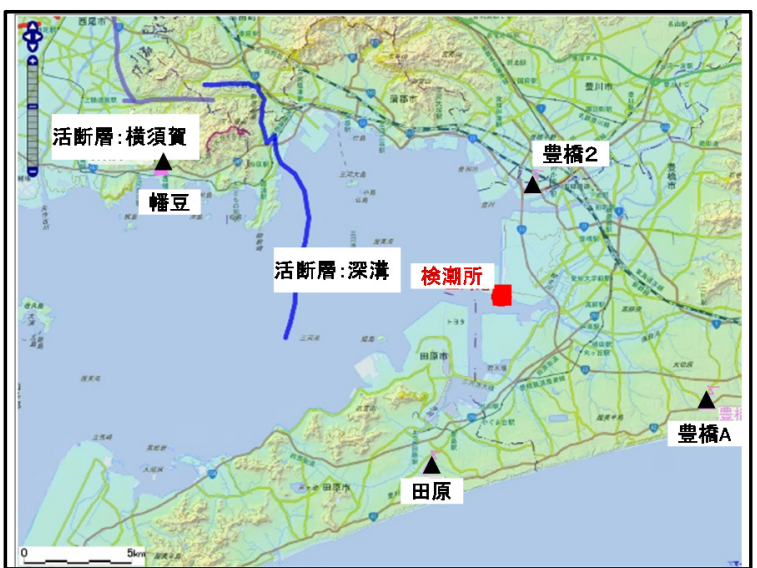

*国土地理院電子地図を元に断層位置を加筆して作成

図-4 三河港周辺の活断層と電子基淮点の平面位置

\section{3. 結果}

（1）三河港検潮所の水準測量履歴

三河港検潮所における取付水準点から観測基準面 （O.D.L）までの高低差の概念図を図-5 に示す，検潮所 の地盤は，不動であるという前提で検潮記録を取得して いる．そのため三河港検潮所では，水準測量と検潮機器 の高低差の変遷履歴を管理している. 取付水準点（二等 水準点 No.901）は，検潮所から直線距離で $4.0 \mathrm{~km}$ 離れた 場所に位置している. 基本水準標は, 2002 年が $2.8841 \mathrm{~m}$, 2016 年が $2.8797 \mathrm{~m}$ と 14 年間で $4.4 \mathrm{~mm}$ 下降していた. 球 分体は, 2002 年の $4.2170 \mathrm{~m}$ から 2016 年は $4.2131 \mathrm{~m}$ と 3.9mm 下降していた. 観測基準面は，2002 年から 2016 年の期間で $2.9 \mathrm{~mm}$ 下降しており, 全体的に下降傾向であ った.

\section{（2）GNSS 測量による球分体楕円体高}

GNSS 測量と検潮所球分体の楕円体高の変動量を図-6 に示す．直接水準測量と GNSS 測量との標高差は $3 \mathrm{~mm}$ から $15 \mathrm{~mm}$ の範囲であった. 3 級水準測量で求められる 精度は，20mm 以内であるため，本測量では精度が十分 に確保されていた. 図-7に検潮所球分体の楕円体高の経 年変動を示寸が，全体としては隆起傾向で，2011 年から 2016 年の 5 年間で $68.4 \mathrm{~mm}$ (13.7mm/year) 上昇していた. 詳細には，2012 年では一旦下降し，2014 年から 2016 年 にかけて上昇していた。

長期的な地盤変動量を把握するため，検潮所の地盤変 動がセミダイナミックパラメータと等しいと仮定し，セ ミダイナミックパラメータによる 1997 年から 2016 年ま での地盤変動量を図-8 に示寸. 三河港検潮所の地盤変動 量は，1997 年から 19 年間で $120 \mathrm{~mm}$ (6.32 mm/year) 上昇 していた，鳥羽，鬼崎検潮所では，三河港検潮所とほぼ 同様の地盤変動量を示していた．名古屋港検潮所，舞阪
検潮所の地盤変動量は，三河港検潮所より変動量が少な いものの上昇していた。 三河港の場合，直近 5 年間では $54 \mathrm{~mm}(10.8 \mathrm{~mm} / \mathrm{year})$ 上昇していた。

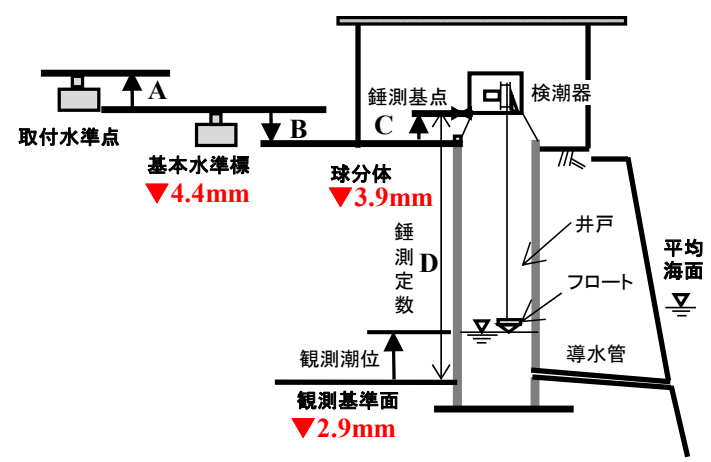

図-5 取付水準点から観測基準面の高低差の変動量

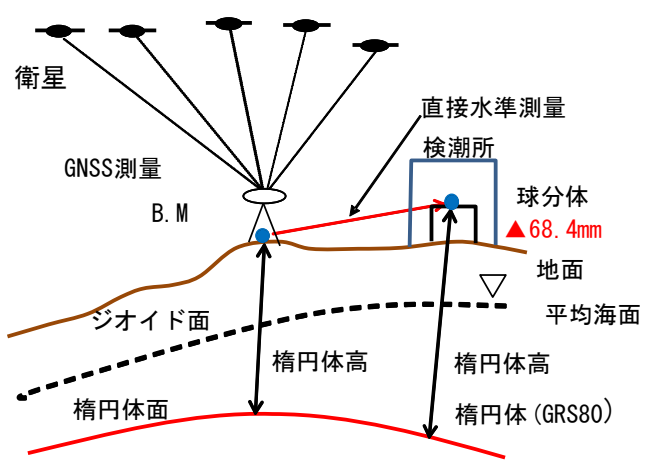

図-6 GNSS 測量による球分体の楕円体高変動量

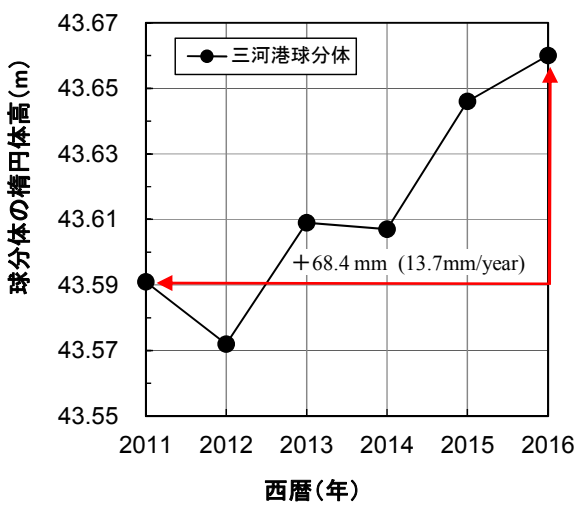

図-7三河港検潮所の球分体楕円体高の経年変動

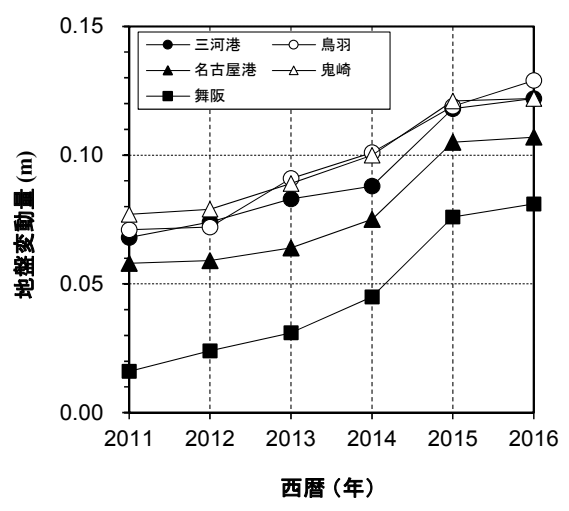

*1997年からの地盤変動量を示す.

図-8 セミダイナミックパラメータによる地盤変動量 


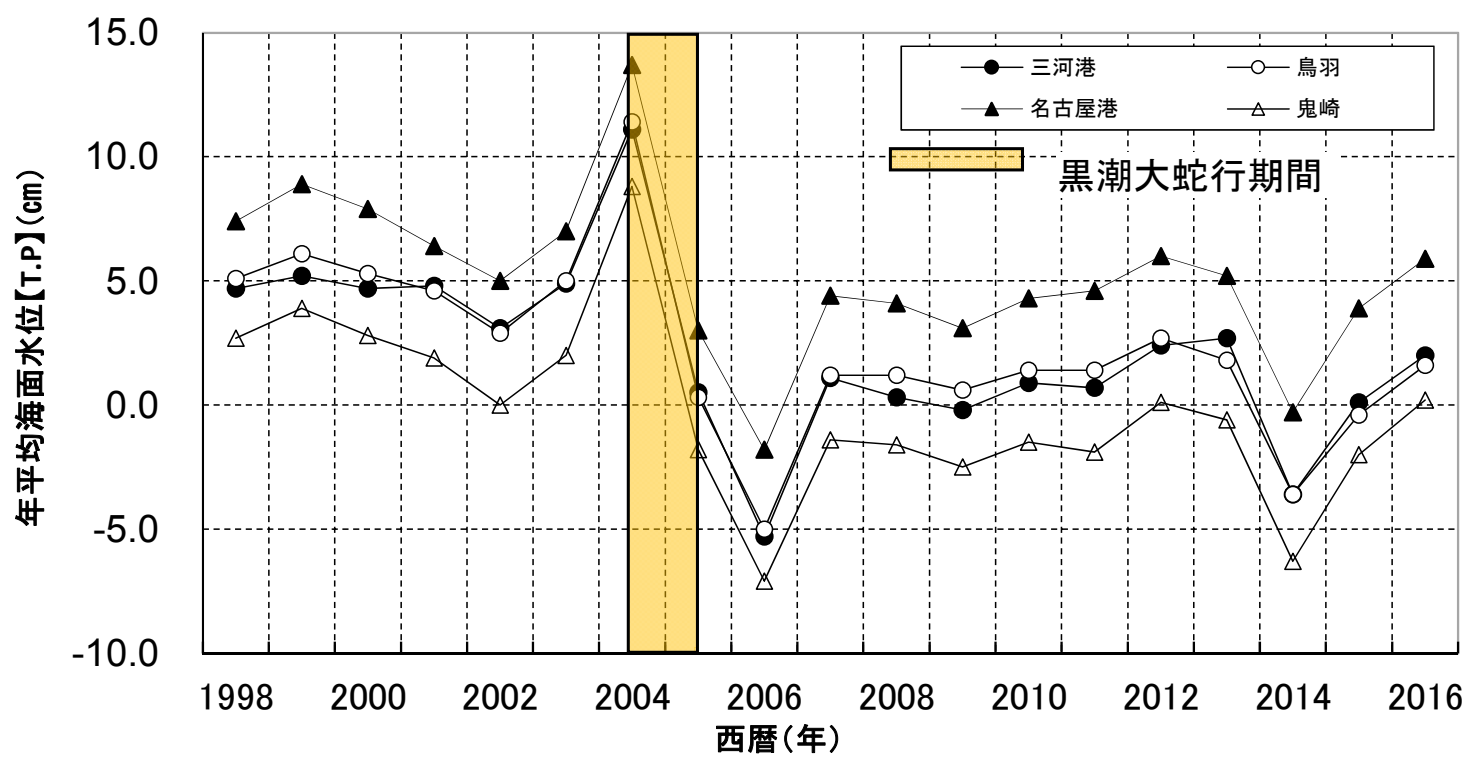

図-9 年平均海面水位の経年変動

表-2 Man Kendall 検定の結果

Mankendall Test

\begin{tabular}{l|cc}
\hline & $\tau$ & \multicolumn{2}{c}{ pvalue } \\
\hline Mikawa & -0.375 & 0.027 \\
Toba & -0.382 & 0.025 \\
Nagoya & -0.322 & 0.059 \\
Onizaki & -0.392 & 0.021 \\
\hline
\end{tabular}

表-3 年平均海面変動量の推定結果

\begin{tabular}{l|rr}
\multicolumn{2}{l}{ Estimete Coefficients } & \multicolumn{1}{c}{$\mathrm{mm} /$ Year } \\
\hline & \multicolumn{1}{|c}{ Coefficients } & \multicolumn{1}{c}{ \pm SE } \\
\hline Mikawa & -3.20 & \pm 1.32 \\
Toba & -3.53 & \pm 1.30 \\
Nagoya & -2.54 & \pm 1.28 \\
Onizaki & -3.34 & \pm 1.31
\end{tabular}

\section{（3）平均海面水位の経年変動}

潮位変動の傾向を把握するため, 図-9 には, 1998 年か ら 2016 年までの平均海面水位の経年変動を示寸. 4 か所 ともに同様な潮位の経年変動を示しており，2004 年から 2006 年の期間では, 平均海面水位が著しく変動していた。 2004 年の 8 月から 2005 年の 7 月までは，黒潮大蛇行の 期間であった. 2014 年は, 各地点ともに前後の年より平 均海面水位が低い傾向があった，各検潮所で得られた年 平均海面水位について，各年の時系列データの間に強い 依存関係は見出されなかった，マンケンドール検定の結 果，1998 年から 2016 年にかけて三河港，鳥羽，鬼崎の 年平均海面水位には有意な変動傾向があった（表-2）。 これらの検潮所における $\tau$ の符号は負であり，年平均海 面水位は有意に低下寸る傾向がみられた (表-2) . また, 名古屋港では年平均海面水位が低下寸る有意傾向が確認
された. 表-3には, 年平均海面変動量の推定結果を示寸. 三河港では, -3.20(mm/year)下降傾向と推定された。鳥羽 は, -3.53(mm/year), 鬼崎が-3.34(mm/year) と同様に海面変 動量が下降傾向を示していた。名古屋港の場合は, -2.54(mm/year) と他の3 地点より海面変動量が少ない傾向 であった.

\section{4. 考察}

\section{（1）地盤変動を考慮した長期海面変動量推定について} 本研究で対象とした三河港検潮所における年平均海 面水位の変動量は，統計的に有意な下降傾向であった. 伊勢湾沿岸に位置寸る鳥羽，鬼崎，名古屋港においても 有意な下降傾向を示していた．この結果から，伊勢湾沿 岸部全体で平均海面水位が下降していることが示唆され るが，常設検潮所での検潮は，あくまで検潮所自体が不 動点であるという条件で行なっている，そのため，平均 海面水位の変化傾向を正確に捉えるには，相対的な地盤 変動の影響を考慮する必要がある. GNSS 測量による三 河港検潮所の球分体楕円高さは, 2011 年から 2016 年の 期間で，13.7(mm/year)上昇している。.また，セミダイナ ミックパラメータを用いた地盤変動量は，10.8(mm/year) とほぼ同様の上昇傾向であった。このことは，三河港検 潮所の変動が，検潮所周辺の変動と同傾向であることを 示しており, 前述の仮定が妥当であることを示している. 検潮所の地盤変動を考慮すると三河港での年平均海面変 動量は，3.12(mm/year) 上昇と推定された。

年平均海面水位は，周期的な変動をしているが，黒潮 大蛇行による影響，海水温低下による影響が示唆されて 
いた．地盤変動は上昇傾向であるものの，2012 年に代表 されるように，年毎に複雑な変動を示している．三河港 の周辺では，1945 年三河地震の際に地震断層（横須賀, 深溝）が出現している. 愛知県中部を北北西一南南東方 向に延びる逆断層である ${ }^{12)}$. これらの断層は，L字型と 逆 L 字型を組み合わせた特異な分布を示しており，その 長さは三河湾海底部も含めると約 $28 \mathrm{~km}$ に達している ${ }^{13)}$ 長期海面変動量を推定するには，平均海面水位の変動と 検潮所の地盤変動について，長期間を対象としたデータ を用いて推定することが望ましい. さらに，平均海面水 位の時系列データは，自己相関が存在する可能性がある ことから，本研究で用いた期間以上の検潮記録を今後集 積していくことが重要である.

平均海面水位の解析対象期間とほぼ同一の期間であ る 1997 年から 2016 年までの年平均地盤変動量は, 6.32(mm/year)であった. 本研究の場合, GNSS 測量の期 間が短いため，セミダイナミックパラメータによる年平 均地盤変動量を用いて年平均海面変動量を推定した. よ り長期間の地盤変動量を用いて, 海面変動量を推定する ことが適切であると考え，年平均海面変動量（18 年間） から長期間（19 年間）の地盤変動量の差分による推定を 行うことは，地盤変動と潮位変動の周期的なイベントに よる影響も考慮できることから，推定手法には妥当性が あるものと考えられる.

\section{（2）被災時の復旧段階における検潮所の高さ管理手法}

被災時における検潮所復旧概念図を図-10に示す.被災 時に検潮所の機能を速やかに復旧するためにはDL面高 さ (図中のC) を確定することが必要である.このため, 被災前は，検潮所の球分体高（準拠楕円体からの高さ）

（図-10中のA）をGNSS測量で測定しAの值を求める. その後，DL面上からの球分体高さBを用いて，準拠楕円 体上のDL面高さCの值を求めておき記録・保管を行う. 被災後は，新B.M.（図-10中 A'）の設置を行うため, 新 B.M.高（準拠楕円体上）をGNSS測量で求めたあとに， 被災前に確定していた楕円体上のDL面高さCの值から， 新B.M高さ (DL面上) B’ を求める.

この対応を行うことにより，元の検潮所があつた付近 に新B.M.の設置を行うことができ，被災前に決定してい た楕円体上のDL面高さを基準とし, 簡易であるものの迅 速に潮位観測を行うことができる. GNSS測量は，衛星 からのデータをもとに楕円体高を直接計測することによ り，標高を計算できる，そのため，常時に計測した楕円 体高から基準面との関係を整理し，その記録を保存・管 理することにより，災害時に被災地周辺の検潮所が損傷 した場合，検潮所の復旧に向けた基準面の高さの確認に 活用できると考えられる.
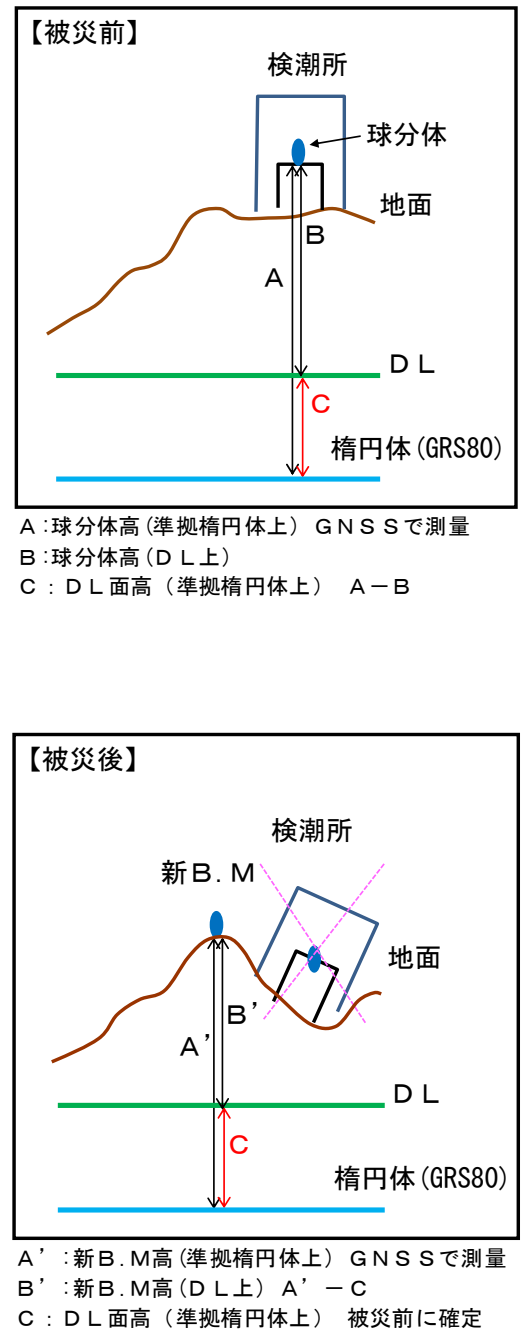

図-10 被災時における検潮所応急復旧の概念図

\section{5. 結論}

本研究では，GNSS測量による地盤変動量を考慮した 長期の海面変動量を推定した. 主な結論は以下のとおり である。

（1） 三河港の年平均海面変動量は，-3.20(mm/year) と有 意な下降傾向であることが推定された. 伊勢湾沿岸 の鳥羽，名古屋港，鬼崎でも，同様に下降傾向であ つた.

（2）三河港の球分体楕円体高は，GNSS 測量による直近 5 年間で $68.4 \mathrm{~mm}(13.6 \mathrm{~mm} / \mathrm{year})$ 上昇していた. 同 期間でセミダイナミックパラメータを用いた地盤 変動量は, $10.8 \mathrm{~mm} / \mathrm{year}$ と同様に上昇傾向であった. このことは，三河港検潮所の変動が，検潮所周辺の 変動と同傾向であることを示している. 
（3）セミダイナミックパラメータによる地盤変動量は, 19 年間で $120 \mathrm{~mm}$ (6.32 mm/year) 上昇していた. 鳥羽, 鬼崎でも同様に上昇していた．地盤変動を考慮する と三河港での年平均海面変動量は, $3.12(\mathrm{~mm} / \mathrm{year})$ 上昇と推定された.

（4）平均海面水位の海面変動量をモニタリングする際 には，平均海面水位の変動のみならず，GNSS 測量 により直接検潮所の球分体楕円体高を測量し，地盤 変動量を考慮することで，周期的なイベントによる 影響が考慮できることから，本研究で提案した推定 手法には一定の妥当性があると考えられる.

（5）地震等による被災後は，地盤変動が発生するため， GNSS 測量による検潮所の高さ管理を平時より行う ことで，速やかに潮位観測の再開が可能となり，深 浅測量の実施を通じて，復旧工事の円滑化に寄与で きる可能性があるものと考えられる.

\section{謝辞}

国土交通省 中部地方整備局 三河港湾事務所 関係各 位には，三河港検潮記録の提供と現地観測においてご協 力を賜りました．国土交通省 国土技術政策総合研究所 海洋環境研究室 秋山吉寛研究官には, 検潮記録の解析に おいてご助言を賜りました。ここに記して深甚なる謝意 を表します。

\section{参考文献}

1）檀原毅：日本における平均海面の永年変化とそれにともな う問題点について, Vol.16, No.1, pp.1-8, 測地学会誌, 1970.

2) 村上和男, 山田邦明: 我国沿岸の潮位と平均海面の変動の 解析, Vol.31, No3, pp.37-70, 港湾空港技術研究所報告, 1992.

3) 櫻井敬三, 小西達男: 日本沿岸の海面水位の長期変動 特性, Vol.72, pp.7-16, 測候時報, 2005 .

4) 三浦優司, 川元智司, 験潮所の GPS 連続測定を用いた潮位 データの解析手法の検討，No23，pp.21-33，国土地理院時 報, 2013 .

5) 内藤了二, 淺井正, 猪俣勉, 川口浩二 : 港湾域におけ 万平均海面水位の推定と長期変動特性, Vol.71, No.2, pp.329-334，土木学会論文集 B3 (海洋開発)， 2015.

6) 電子基準点データ提供サービス, http://terras.gsi.go.jp/, 国土地理院 HP, 2018.

7) ジオイド高計算, http://terras.gsi.go.jp/，測量計算サイ 卜, 2018.

8) 過去の気象データ検索, http://www.data.jma.go.jp/obd/s tats/etrn/index.php, 気象庁 HP, 2018.

9) 気象庁 : 潮位表, http://www.data.jma.go.jp/gmd/kaiyou/ $\mathrm{db} / \mathrm{tide} / \mathrm{suisan} / \mathrm{index}$.php, 2018.

10) 気象庁: 潮汐観測資料, http://www.data.jma.go.jp/gmd/ kaiyou/db/tide/genbo/index.php, 2018.

11）国土地理院: 潮位デー夕提供 国土地理院験潮場一覧, http://www.gsi.go.jp/kanshi/tide_furnish.html, 2018.

12）活断層研究会編：[新編]日本の活断層分布図と資料, pp.1-437, 東京大学出版会, 1991.

13）杉戸信彦, 岡田篤正: 1945 年三河地震の地方地震断層, 活断層研究, Vol.24 pp.103-127, 2018.

(2018.2.8 受付)

\title{
ESTIMATION OF LONG-TERM SEA LEVEL VARIATION TAKING INTO CON- SIDERATION GROUND DEFORMATION BY GNSS SURVEY
}

\author{
Ryoji NAITO, Kazunori SAMESHIMA, Yasunori KONDOU, \\ Naokazu ITO and Koji KAWAGUCHI
}

For estimating long-term sea level variation, periodical corrective adjustments by measuring the degree of ground deformation are required which are done by surveyors' levelling from the 1st class benchmark to the levelling spot at the tidal station. However, due to the issues of increasing costs of such manual levelling works and shortage of young surveyors, finding a simpler method of measuring ground deformation has become an urgent issue. In this study, we estimated sea level variation using a GNSS (i.e. global navigation satellite system) survey to grasp the level of ground deformation. At the Port of Mikawa, annual sea level variation was estimated to be -3.20 ( $\mathrm{mm} /$ year) based on the tide observation record, while the same decreasing tendency was observed at the Ports of Toba, Nagoya and Onizaki which are all located along Ise bay.

However, due to ground deformation, the GNSS survey shows that the height of the levelling spot at the tidal station at the Port of Mikawa increased by $68.4 \mathrm{~mm}$ in 5 years $(13.7 \mathrm{~mm} /$ year) while the ground elevation estimation using the semi-dynamic correction of the geodetic framework shows that the area of Port of Mikawa rose by $120 \mathrm{~mm}$ in 19 years $(6.32 \mathrm{~mm} /$ year $)$. Based on the magnitude of the ground deformation, the sea level at the Port of Mikawa is estimated to be rising at a rate of $3.12 \mathrm{~mm}$ per year.

Furthermore, the authors proposed a method to control the height of the levelling spot at the tidal station when recovering from the disasters. 